\title{
Tomato Yield and Quality Response to Water Application Technique and Management
}

\author{
Tom Gashari, Semwogerere Twaibu, Samuel Baker Kucel, and David Magumba
}

\begin{abstract}
Tomato (Lycopersicon esculentum Mill) is one of the most important and has the highest acreage of any vegetable crop in the world. Such quantitative analysis is based on the assessment of data from sequential collections of plant traits linked to environmental conditions, as well as yield potential under optimal growth conditions. The objective in this study was to evaluate the performance of tomato crop under furrow, basin and hosepipe irrigation techniques in Kabos, Serere District of Eastern Uganda. The materials and methods used in this study included tools like water pump (model DCX2-50D), Tomato variety Rionex, weighting scale, CROPWAT 8.0 software, CANOPEO software among others. Generally, quantitative techniques through several experiment designs were used. Daily and monthly weather variables, in-situ primary datasets of plant height, canopy cover percentages and fruit characteristics, and weight of harvested tomatoes were measured at three growth stages and analyzed using RCBD experiment with six treatments and four replications.

Findings showed that overhead treatments had lowest rate of rotten yield compared to basin and furrow but had highest rate of discolored fruits attributed to sunshine and impact of water pressure during irrigation. Rotting of yield was highest in basin treatments. The rotting was attributed to water logging, poor drainage that accelerated fungal infection in the tomatoes. Furrow treatments had better drainage which reduced quantity of nonmarketable yield. There was no significant difference on the weight of tomatoes below $65 \mathrm{~g}$. This meant that fruit weight was independent of irrigation method. Treatments under hosepipe irrigation-overhead. Conclusively, water management practices have big impact on the crop yield giving a relationship that yield is directly proportional to water management practices, which however, should be followed by detailed soil and water analysis through such studies. The Safe-Water-for Food (SWFF) target can be reached and eventually reduce on the global hunger syndrome.
\end{abstract}

Keywords - Hunger, Irrigation, Safe-Water-for-Food, Tomato Yield, Water Treatment.

\section{INTRODUCTION}

The tomato crop is globally an economically advantaged once its yield is sorted positively [1]. In 2010, its global production was approximately 145.6 million tons of fresh fruit [2]. Global production levels of vegetables tomatoes inclusive increased by 55\% between 1993 and 2003 [3], the majority of this increase coming from area expansion.

Submitted on December 05, 2021.

Published on December 29, 2021

Tom Gashari, Busitema University, Uganda.

(e-mail: tomgashali@yahoo.com)

Semwogerere Twaibu, Busitema University, Uganda.

(e-mail: tsemwogerere@eng.busitema.ac.ug).
Growth in productivity (yields per unit area) is limited with approximately $0.5 \%$ annually. In Uganda total vegetable production increased with $23 \%$ to a total of $556,000 \mathrm{Mt}$ in 2003. Given the area increase of $30 \%$ a logical conclusion is that overall productivity of vegetable production declined.

Tomato growing is considered a high risk activity due to the great variety of environments and systems in which it is grown. It is highly susceptible to pests and diseases, and has high demand for inputs and services, which lead to high financial investment per unit area. Furthermore, Lopes and others [4] remarked that good productivity requires availability of water throughout the cycle [5], as the tomato plant is very sensitive to water stress. The commercial value of the table tomato is defined by the characteristics and quality of the fruit [6].

In many developing countries, growing demand for irrigation, as well as increased population and limited water management are placing increasing pressure on water resources. The increasing worldwide shortages of safe water and costs of irrigation are leading to an emphasis on developing methods of irrigation that minimize water use but maximize the productivity) [7].

The amount of water applied to crop, along with other production factors, allows changes in growth [8]. Such quantitative analysis is based on the assessment of data from sequential collections, in order to describe changes in production of dry matter depending on time, by calculating growth rates. In addition, it allows identifying plant traits linked to environmental conditions, as well as yield potential under optimal growth conditions. According to Pereira [9], the technique provides expressive information about plant growth, requiring data obtained without any sophisticated equipment [10]. The objective in this study was to evaluate performance of tomato crop under furrow, basin and hosepipe irrigation techniques in Kabos, Serere District of Eastern Uganda.

\section{Materials AND Methods}

This study was done in Kabos shown in Fig. 1, a site promoting Horticulture and Irrigation Innovations in Eastern Uganda in collaboration with Teso Women in Development Initiative (TEWEDI), University of California and Busitema University. The choice of this study area was influenced by

Samuel Baker Kucel, Busitema University, Uganda.

(e-mail: sbkucel@gmail.com)

David Magumba, Busitema University, Uganda.

(e-mail: davmagumba ${ }^{\circledR}$ gmail.com). 
water availability for Irrigation from Lake Kyoga, near normal rainfall events and available installed irrigation system. It is located at an altitude of $1123 \mathrm{~m}$ and coordinate of $33.61^{\circ} \mathrm{E}$ and $1.71^{\circ} \mathrm{N}$ North-West of Serere town covering an area approximately $102 \mathrm{~km}^{2}$.

\section{LOCATION OF THE SITE IN SERERE DISTRICT}

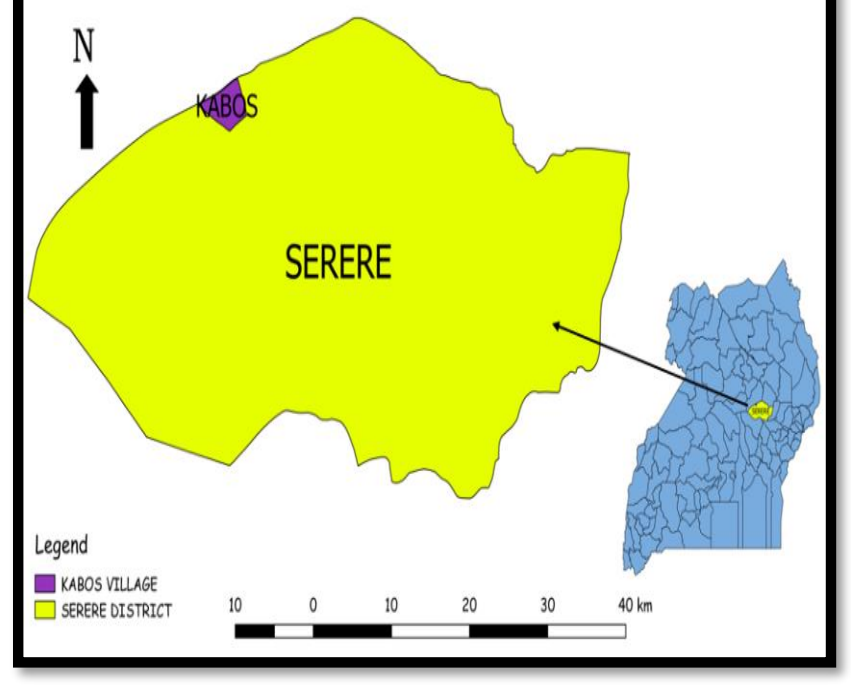

Fig. 1. Location of Study Site at Kabos in Serere District.

In this area, there is a combination of Rainfed Agriculture where cassava and tomatoes are major crops among others. The materials used in this study were water pump (model DCX2-50D, Tomato (variety Rionex), $100 \mathrm{~m}$ flexible tape measure, Digital weighting scale, CROPWAT 8.0 software, CANOPEO software. Manure, Fertilizer DAP and half of the nitrogen fertilizer were incorporated to the experimental plots before planting while the rest of the nitrogen was applied two weeks after the establishment of seedlings. Other agronomic practices (weeding, cultivation, pruning, etc.) were applied uniformly to all plots following standard agronomic recommendation for tomato cultivation. Fungicides (Ridomil + MZ 63\% and Mancozeb $3.5 \mathrm{~kg} \mathrm{ha}^{-1}$ ) were applied to control leaf disease and cypermethrin (100 g.a.i ha-1) was used to control insect pests. The pesticides were sprayed at seven days interval from transplanting to 20 days before first harvest. The experiment was laid out in randomized complete block design with four replications. Daily and monthly weather variables such as: solar radiation, max and min temperature, max and min Relative Humidity, wind speed and rainfall for the experimental period were obtained from Soroti weather station; the nearest station to the experimental site. In-situ primary datasets like plant height, canopy cover percentages, fruit characteristics, weight of harvested tomatoes (marketable and non-marketable) were measured at three growth stages. In order to make comparisons and analysis in the growth and yield, Randomized Complete Block Design experiment was done with six treatments and four replications. Analysis of variance took the form presented in Table I.
TABLE I: RANDOMIZED COMPLETE BLOCK DESIGN ANOVA

\begin{tabular}{ccccc}
\hline $\boldsymbol{S O V}$ & $\boldsymbol{D} \boldsymbol{f}$ & $\boldsymbol{S S}$ & \multicolumn{1}{c}{$\boldsymbol{M S}$} & $\boldsymbol{F c a l}$ \\
\hline Total & $r t-1$ & $T S S$ & & \\
Treatment & $t-1$ & $S S T$ & $S S T /(t-1)$ & \multirow{2}{*}{ MST $/ M S E$} \\
Block & $r-1$ & $S S B$ & $S S B /(r-1)$ & \\
\multirow{2}{*}{ Error } & $(r-1)(t$ & $T S S-S S T$ & $S S E /(r$ & \\
& $-1)$ & $-S S B$ & $-1)(t-1)$ & \\
\hline
\end{tabular}

Conclusions based on the Analysis of Variance (ANOVA) in Table I were arrived at after comparing Calculated $\mathrm{F}$ values with the Tabulated F-values at $1 \%$ and $5 \%$ as below. This guideline was presented by Montgomery, Douglas C., in 2002.

i. If Fcal $>$ Ftab at $1 \%$ Confidence Interval (CI) then the difference in the treatment mean is highly significant denoted by two asterisks $(* *)$.

ii. If $\mathrm{Fcal}>\mathrm{Ftab}$ at $5 \% \mathrm{CI}$ but less than $\mathrm{F}_{\text {tab }}$ at $1 \% \mathrm{CI}$, then the difference in the treatment mean is significant denoted by one asterisk $(*)$.

iii.If $\mathrm{Fcal}<\mathrm{Ftab}$ at $5 \% \mathrm{CI}$, then the difference in the treatment mean is none significant denoted by (ns).

\section{A. Crop Water Requirements}

Establishment of crop water requirements using CLIMWAT 2.0, climatic data was obtained at $1123 \mathrm{~m}$ altitude and coordinate of $33.61^{\circ} \mathrm{E}$ and $1.71^{\circ} \mathrm{N}$ using Soroti Weather station of Uganda. The following are the climatic data that were obtained; Temperature (both minimum and maximum), Humidity, wind speed, sunshine hours, and radiation. CROPWAT 8.0 was then used to calculate crop water need (CWN) considering tomatoes growth stages (initial, development, mid-season, and late season) and three decades. It was taken that tomatoes were planted in the 2018 first planting season. Applying FAO Penman-Monthieth Equation and empirical formula, daily evapotranspiration $\left(E T_{o}\right)$ and effective rainfall were calculated. The output from CROPWAT 8.0 is presented in TABLE 3. The soil type in the study area is Black clay loam to be irrigated at critical depletion level and refilling it to field capacity and yield reduction was set to $0.1 \%$.

The crop water requirement $\left(E T_{c}\right)$ for the tomatoes crop was determined using (1):

$$
E T_{c}=E T_{o} K_{c}
$$

where, $E T_{c}$ is the crop water requirement, $\mathrm{mm} / \mathrm{day} ; E T_{o}$ is the reference crop evapotranspiration, $\mathrm{mm}$ /day and $K_{c}$ is the crop coefficient. The crop water requirement was specifically determined for the days in the months of the crop growing season. This included January, February, March, April, May and June. The reference Crop Evapotranspiration $\left(E T_{o}\right)$ was calculated using Modified Penman-Monteith Equation:

$E T_{o}=\frac{0.408 \Delta\left(R_{n}-G\right)+\gamma \frac{900}{(T+273)} U_{2}\left(e_{s}-e_{a}\right)}{\Delta+\gamma\left(1+0.034 U_{2}\right)}$

where $E T_{o}$ is the reference crop evapotranspiration (mm/day); $R_{n}$ is the net radiation at the crop surface [MJ m-2 day $\left.^{-1}\right] ; G$ is the soil heat flux density $\left[\mathrm{MJ} \mathrm{m}^{-2}\right.$ day $\left.^{-1}\right] ; T$ is the air temperature at $2 \mathrm{~m}$ height, ${ }^{\circ} \mathrm{C} ; U_{2}$ is the wind speed at $2 \mathrm{~m}$ height, $\mathrm{m} \mathrm{s}^{-1} ; e_{s}$ is the saturation vapor pressure, $\mathrm{kPa} ; e_{a}$ is the actual vapor pressure, $\mathrm{kPa} ; e_{s}-e_{a}$ is the saturation vapor 
pressure deficit, $\mathrm{kPa} ; \Delta$ is the slope of vapor pressure curve, $\mathrm{kPa}{ }^{\circ} \mathrm{C}^{-1}$ and $\gamma$ is the psychometric constant, $\mathrm{kPa}^{\circ} \mathrm{C}^{-1}$.

According to FAO [11], the crop coefficient for any period of the growing season can be derived by considering that during the initial and mid-season stages $K_{c}$ is constant and equal to the $K_{c}$ value of the growth stage under consideration. During the crop development and late season stage, $K_{c}$ varies linearly between the $K_{c}$ at the end of the previous stage ( $K_{c}$ prev) and the $K_{c}$ at the beginning of the next stage ( $K_{c}$ next), which is $K_{c}$-end in the case of the late season stage.

Equation (3) below was used in this computation.

$K_{c i}=K_{c \text { prev }}+\left\{\frac{i-\sum\left(L_{\mathrm{prev}}\right)}{L_{\text {stage }}}\right\}\left(K_{c \text { next }}-K_{c \text { prev }}\right)$

where $i$ is the day number within the growing season; $K_{C} i$ is the crop coefficient on day $i ; L_{\text {stage }}$ is the length of stage under consideration (days) and $\sum\left(L_{\text {prev }}\right)$ is the Sum of length of all the previous stages (days).

\section{B. Determination of Net Irrigation Water Requirement (NIR)}

The net Irrigation requirement was calculated using Equation 4 embedded in CROWAT 8.0 model.

$$
N I R=E T_{c}
$$

where $N I R$ is the net irrigation is water requirement $(\mathrm{mm})$ and $E T_{c}$ is the crop water requirement (mm/day). The effective rainfall values $\left(P_{e} \mathrm{~mm}\right)$, Equations 5 and 6 , were determined based on the empirical formula embedded in the CROPWAT 8.0 Model. i.e.:

$$
\begin{gathered}
P_{e}=\frac{0.5 \mathrm{P}-5}{3}, \text { if } \mathrm{p}<\frac{50}{3} \\
P_{e}=\frac{0.7 \mathrm{P}+20}{3}, \text { if } \mathrm{p}>\frac{50}{3}
\end{gathered}
$$

Where $\mathrm{p}$ is the precipitation in $\mathrm{mm} / \mathrm{month}$.

Gross Irrigation requirement $(G I R)$ is the total amount of water needed to irrigate a field-to-field capacity. It is calculated using input from (4) and (7) below adapted from FAO [11]:

$$
G I R=\frac{N I R}{E}
$$

Where $\mathrm{E}$ is the Irrigation Efficiency set at $70 \%$

\section{Experimental Setup}

Tomatoes in all treatments were planted in 4 rows spaced at $0.9 \times 0.5 \mathrm{~m}$, with a $0.2 \mathrm{~m}$ gap to the plot edge on both sides with 6 plants in each row and a total of 24 plants per plot. Fig. 2 below shows the experimental layout.

The method used to distribute Irrigation water per plot was as follows. Using 24 experimental plots, Fig. 2, irrigation water was divided by 24 to give irrigation water per plot. The time for delivering $100 \%$ of irrigation water per plot was recorded, to ensure that only $50 \%$ of irrigation water per plot was applied, a half of the time to supply $100 \%$ was used. Table II shows experimental treatments and water distribution in them.

\begin{tabular}{|c|c|c|}
\hline $\begin{array}{l}\text { Plot } \\
\text { Code }\end{array}$ & $\begin{array}{l}\text { Irrigation } \\
\text { Technique }\end{array}$ & Description \\
\hline 1 & Overhead Low & $\begin{array}{l}\text { Flat field under rain-fed agriculture with } \\
50 \% \text { GIR per plot using Hosepipe } \\
\text { technique }\end{array}$ \\
\hline 2 & Overhead High & $\begin{array}{l}\text { Flat field under rain-fed with } 100 \% \text { GIR } \\
\text { per plot using Hosepipe technique }\end{array}$ \\
\hline 3 & Furrow Low & $\begin{array}{l}\text { Furrow field under rain-fed farming with } \\
50 \% \text { GIR per plot }\end{array}$ \\
\hline 4 & Furrow High & $\begin{array}{l}\text { Furrow field under rain-fed with } 100 \% \\
\text { GIR per plot. }\end{array}$ \\
\hline 5 & Basin Low & $\begin{array}{l}\text { Basin field under rain-fed with } 50 \% \text { GIR } \\
\text { per plot }\end{array}$ \\
\hline 6 & Basin High & $\begin{array}{l}\text { Basin field under rain-fed with } 100 \% \\
\text { GIR per plot }\end{array}$ \\
\hline
\end{tabular}

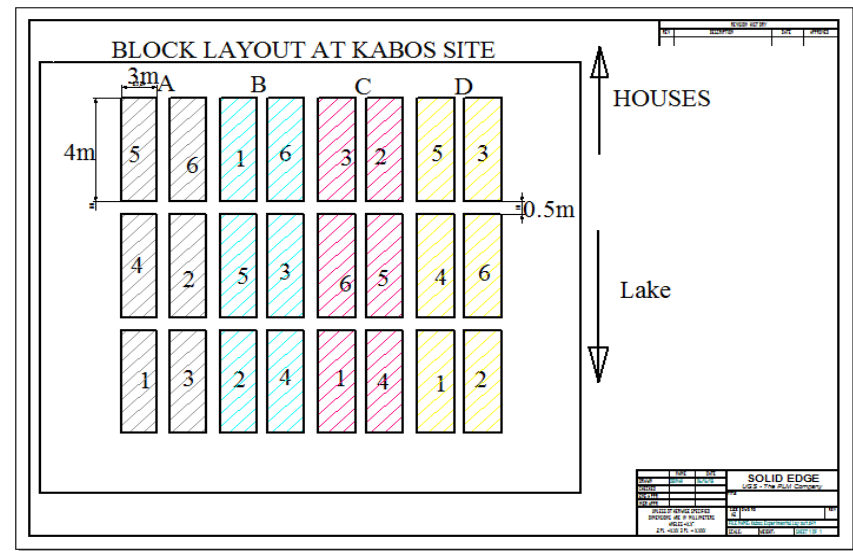

Fig 2. Experimental Layout

TABLE II: TREATMENT APPLIED TO EXPERIMENTAL PLOTS

\section{Monitoring Crop Growth, Harvesting and Fruit Sampling}

Six plants representing all the treatments in each block were selected randomly and monitored throughout the growing season. This was accomplished by collecting data on; crop height (mm), canopy cover (\%) and Fruit Yield (Kg) and Average height $(\mathrm{mm})$ at three critical growth stages: 20 DAT, 40 DAT and 70 DAT (DAT- Days after transplanting). Tomato fruit were hand-harvested at full maturity and ripening. Yield components for tomato including fruit mass, fruit size and fruit number were determined. Fruit sizes were estimated by measuring the fruit diameter employing the use of handheld venire caliper. At the termination of the experiment.

\section{E. Yield per Plot}

Tomato fruits were harvested when they had attained physiological maturity and ripened. The fresh weights of fruits $(\mathrm{kg})$ per block and treatment were recorded and the average weight calculated in ton per hectare (t/ha). The yields were clustered under: Marketable (t/ha), that which weighs $65 \mathrm{~g}$ and above in addition to other quality characteristics. Those weighing less than $65 \mathrm{~g}$ and those with small Size, discolored, Diseased, Heat affected etc. were classified under the non-Marketable fruits as presented by Prakash Babu Adhikari, [12].

\section{F. Statistical Analysis}

The Genstat discovery statistical package was used to analyze the data. RCDB ANOVA was used to determine the effect of irrigation method and depth for the dependent variables. Least Square means was used for the post-hoc (multiple comparisons) testing. 


\section{RESULTS AND DISCUSSIONS}

\section{A. The Reference Crop Evapotranspiration (ETO)}

This was obtained using CROPWAT 8.0 employing average climatic parameters, Table III. Temperature range increased from $17.2{ }^{\circ} \mathrm{C}$ to $33^{\circ} \mathrm{C}$, Relative humidity averaged $68 \%$ with sunshine hours being observed to be 7.1 hours, implying crop water need clearly seen by moderate $\mathrm{ET}_{0}$ average of $4.82 \mathrm{~mm} /$ day.

\section{B. Calculation of Crop Factor (KC).}

The initial and mid-season stages of growth have a constant value of crop coefficient, for tomato crop it is taken as $0.6 \mathrm{~mm} /$ day and $1.15 \mathrm{~mm} /$ day respectively, extracted from Allen \& others and FAO [11], [13].

During the crop development and late season stage, $K c$ varies linearly between $K c$ prev and $K c$ next, which is $K c$-end in the case of the late season stage. It is noted that high $\mathrm{Kc}$ value yields high ETc value, a relationship depicted from (1). $K c$ Values obtained from CROPWAT 8.0 model are 0.6, 1.15 and 0.8 in the initial, development and late stages respectively. The plot of the $K c$ values in Fig. 3 shows that the values increase exponentially during the crop development stage until a maximum value is attained, this is constant for the next 20 days and decreases towards the late season stage.

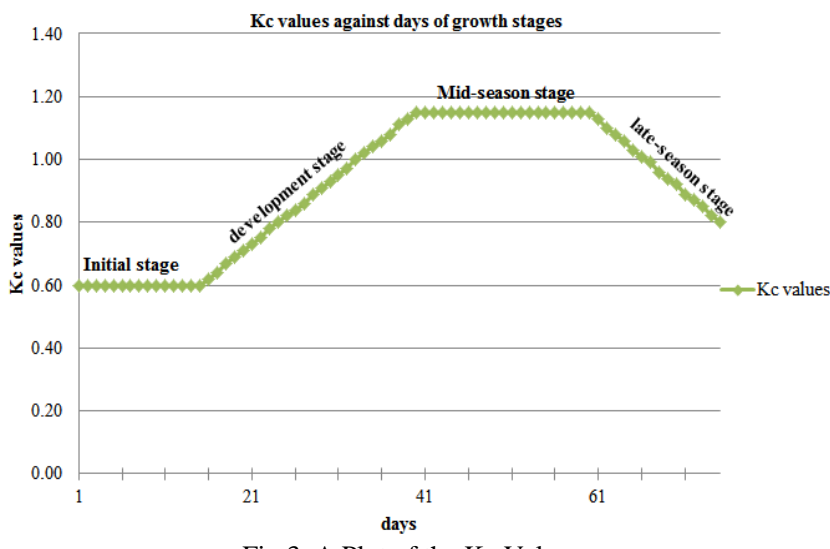

Fig.3. A Plot of the Kc Values

\section{Determination of Crop Water Requirement and Irrigation Water Requirement}

Table IV shows the input and output of the CROPWAT 8.0 model as generated. From this data, a graph of water requirement against growth stages was plotted shown in Fig. 4. This plot shows an increasing trend in the crop water need up to mid-development stage attributed to the reason that the crop has reached maturity, a sign exhibited by many crops. The relationship exhibited between ETc and the irrigation requirement is that crop water use is weather, soil, water and plant dependent. This is in line with the findings presented by Al Kaisi and Broner [14].

TABLE III: AvERAGE ClimATIC PARAMETERS FROM CLIMWAT 2.0

\begin{tabular}{cccccccc}
\hline Month & Min Temp & Max Temp & Humidity & Wind & Sun & Rad & ET0 \\
\hline Jan & ${ }^{\circ} \mathrm{C}$ & ${ }^{\circ} \mathrm{C}$ & $\%$ & $\mathrm{~km} /$ day & hours & $\mathrm{MJ} / \mathrm{m}^{2} /$ day & Mm/day \\
Feb & 18 & 32.8 & 53 & 199 & 7.1 & 19.5 & 5.40 \\
March & 18.7 & 33 & 55 & 199 & 7.9 & 21.4 & 5.71 \\
April & 19 & 32.2 & 59 & 190 & 7.6 & 21.4 & 5.50 \\
May & 18.6 & 30 & 68 & 173 & 7.2 & 20.4 & 4.75 \\
June & 18.1 & 28.7 & 73 & 173 & 7.6 & 19.9 & 4.34 \\
July & 17.7 & 28.2 & 72 & 173 & 7.2 & 18.7 & 4.11 \\
Aug & 17.3 & 27.5 & 73 & 190 & 6.1 & 17.4 & 3.90 \\
Sept & 17.2 & 27.8 & 73 & 173 & 6.7 & 19.1 & 4.12 \\
Oct & 7.3 & 29.2 & 70 & 173 & 7.5 & 20.9 & 4.61 \\
Nov & 17.6 & 30.3 & 66 & 173 & 8 & 21.6 & 4.92 \\
Dec & 17.7 & 31 & 60 & 199 & 7.7 & 20.4 & 5.12 \\
Average & 17.8 & 31.5 & 57 & 216 & 7.8 & 20.2 & 5.31 \\
\hline
\end{tabular}

TABLE IV: CROP WATER REQUIREMENT FROM CROPWAT MODEL

\begin{tabular}{|c|c|c|c|c|c|c|c|}
\hline \multicolumn{8}{|c|}{ Crop water requirement } \\
\hline \multirow{2}{*}{\multicolumn{2}{|c|}{$\begin{array}{l}\text { ETo Station: Soroti } \\
\text { Rain station: Soroti }\end{array}$}} & \multirow[b]{3}{*}{ Stage } & \multirow[b]{3}{*}{$\begin{array}{c}K c \\
\text { Coef }\end{array}$} & \multirow[b]{3}{*}{$\begin{array}{c}E T c \\
\mathrm{~mm} / \text { day }\end{array}$} & \multirow{2}{*}{\multicolumn{3}{|c|}{$\begin{array}{l}\text { Crop: TOMATOES (Cro) } \\
\text { Planting Date: } 19 / 01 / 2019\end{array}$}} \\
\hline & & & & & & & \\
\hline Month & Decade & & & & $\begin{array}{c}E T c \\
\mathrm{~mm} / \mathrm{dec}\end{array}$ & $\begin{array}{l}\text { Eff rain } \\
\mathrm{Mm} / \mathrm{dec}\end{array}$ & $\begin{array}{r}\mathrm{CWN} \\
\mathrm{mm} / \mathrm{dec}\end{array}$ \\
\hline Jan & 2 & Ini & 0.60 & 3.24 & 6.5 & 2.2 & 6.5 \\
\hline Jan & 3 & Ini & 0.60 & 3.30 & 6.3 & 12.4 & 24.0 \\
\hline Feb & 1 & Ini & 0.60 & 3.36 & 33.6 & 13.8 & 19.8 \\
\hline Feb & 2 & Dev & 0.67 & 3.80 & 38.0 & 15.1 & 22.9 \\
\hline Feb & 3 & Dev & 0.83 & 4.67 & 37.3 & 17.2 & 20.1 \\
\hline March & 1 & Dev & 0.99 & 5.53 & 55.3 & 13.8 & 27.4 \\
\hline March & 2 & Mid & 1.13 & 6.25 & 62.5 & 19.1 & 33.4 \\
\hline March & 3 & Mid & 1.14 & 6.03 & 66.3 & 27.6 & 38.7 \\
\hline April & 1 & Mid & 1.14 & 5.74 & 57.4 & 39.1 & 18.3 \\
\hline April & 2 & Late & 1.14 & 5.43 & 54.3 & 47.8 & 6.4 \\
\hline April & 3 & Late & 1.03 & 4.77 & 47.7 & 46.8 & 0.9 \\
\hline May & 1 & Late & 0.88 & 3.95 & 39.5 & 45.6 & 0.0 \\
\hline May & 2 & Late & 0.79 & 3.43 & 26.9 & 9.2 & 6.9 \\
\hline & & & & & 541.5 & 313.6 & 245.4 \\
\hline
\end{tabular}




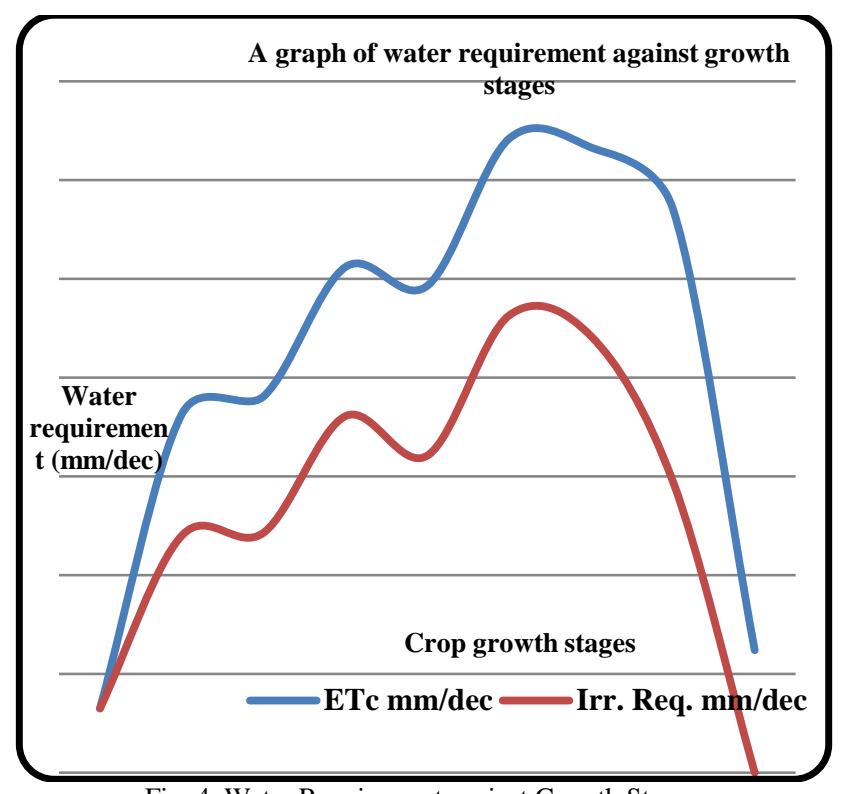

Fig. 4. Water Requirement against Growth Stages.

As observed from Fig. 4, the highest crop water requirement was observed in the first and second decades of March which was an indication of the Mid-season stage during which the tomatoes were fruiting and hence needed more water, meanwhile during the third decade of March and first decade of April, there was a drop in crop water requirement indicating maturity and ripening of the fruits hence low water demand.

\section{Tomato Plant Study}

Table $\mathrm{V}$ provides average height of the plants at three critical growth and RCBD ANOVA analysis of plant heights at 70 DAT while Fig. 5 below shows the variation of height per treatment at different growth stages.

TABLE V: Average Height of the Plants at Three CRITICAL GROWTH AND RCBD ANOVA

\begin{tabular}{|c|c|c|c|c|c|c|c|c|}
\hline \multicolumn{9}{|c|}{ GROW } \\
\hline Stage & $1 \ldots$ & $3 .$. & 6 & $\begin{array}{c}\text { Source of } \\
\text { variation }\end{array}$ & d.f. & s.s. & m.s. & v.r. \\
\hline Initial & 16 & 17 & 16 & $\begin{array}{c}\text { Treatment } \\
\text { stratum }\end{array}$ & 5 & 475.8 & 95.16 & 2.3 \\
\hline Development & 34 & 39 & 30 & Block & 3 & 39.03 & 13.01 & 0.32 \\
\hline \multirow[t]{2}{*}{ Harvest } & 61 & 65 & 59 & Residual & 15 & 608.91 & 40.59 & \\
\hline & & & & Total & 23 & 1123.74 & & \\
\hline
\end{tabular}

Following Fig. 5, it is observed that in the initial stage, plants averaged height of average $16.5 \mathrm{~cm}$. At development stage, plants under furrow Irrigation (treatment 4) showed highest rate of growth while plants under basin. Irrigation (treatment 6) exhibited lowest growth rate. Calculations from Table $\mathrm{V}$ above, showed that $F_{\text {cal }}=0.81$ and $F_{\text {tab }}=9.01$ and 28.24 at $95 \%$ and $99 \%$ confidence interval. Since $F_{\text {cal }}<F_{\text {tab }}$ at $\alpha=0.05$ and 0.01 , then, there is non-significant difference in the mean height at 70DAT, showing no need to repeat the experiment. This conclusion is in line with the guideline presented in Douglas Montgomery [15].

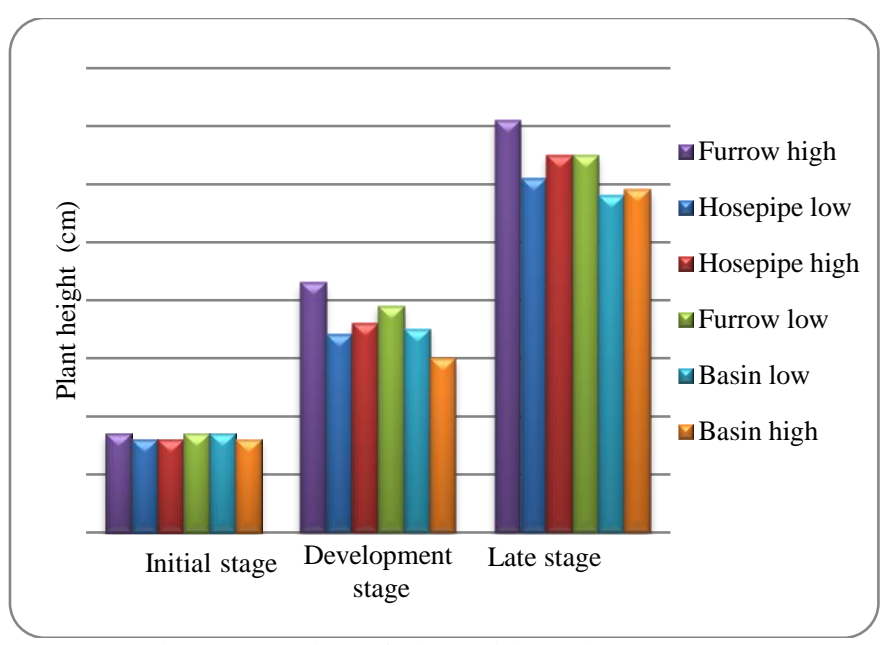

Fig. 5. Comparison of Plant Height at Three Stages.

\section{E. Canopy Cover}

A slight variation was observed on the canopy cover amongst the six treatments during the three critical stages of growth. Treatment 3 had the lowest growth rate while Treatment 4 exhibited greatest growth rate observed by a greater increase in canopy cover (Table VI).

TABLE VI: CANOPY COVER RESULTS

\begin{tabular}{ccccccc}
\hline \multirow{2}{*}{ Stage } & \multicolumn{7}{c}{ Treatments } \\
\cline { 2 - 7 } & 1 & 2 & 3 & 4 & 5 & 6 \\
\hline 20 DAT & 8.25 & 8.55 & 9 & 9.28 & 9.1 & 8.9 \\
40 DAT & 31.6 & 33.5 & 30.8 & 35.3 & 31.6 & 21.9 \\
70 DAT & 40.3 & 38.3 & 20 & 41.4 & 40.2 & 31.7 \\
\hline
\end{tabular}

\section{F. The Crop Yield}

pr. Ripe fruits were harvested, weighed, and sorted into Marketable and non-Marketable yields. Table VII shows the yield results per treatment. This research found out that $0 . \$$ Marketable yield reduces with poor water management ${ }^{1 \text { ns }}$ practices seen at treatment 6 and 5 where surface ponding instigated disease, root damage and fruit rotting.

It was observed from Table VII, that Marketable yield was higher than non-Marketable yield in most treatments. Treatment 4 produced the highest gross yield and Marketable yield attributed to proper drainage and effective supply of irrigation water. Recommendations of Department of Agriculture, Forestry and Fisheries of the Republic of South Africa supports that tomatoes yield is highest in surface Irrigation methods compared to overhead sprinkler methods.

TABLE VII: AVERAGE YIELD PER TREATMENT PLOT

\begin{tabular}{ccccccc}
\hline \multirow{2}{*}{ Treatment } & $\begin{array}{c}\text { Gross } \\
\text { yield }\end{array}$ & $\begin{array}{c}\text { Marketable } \\
\text { yield }\end{array}$ & $\begin{array}{c}\text { Non-Marketable } \\
\text { yield }\end{array}$ & $\begin{array}{c}\text { Gross } \\
\text { Yield }\end{array}$ & $\begin{array}{c}\text { Marketable } \\
\text { Yield }\end{array}$ & $\begin{array}{c}\text { Non-Marketable } \\
\text { Yield }\end{array}$ \\
\cline { 2 - 7 }$(\mathrm{kg})$ & $(\mathrm{kg})$ & $(\mathrm{kg})$ & $\mathrm{t} / \mathrm{ha}$ & $\mathrm{t} / \mathrm{ha}$ & $\mathrm{t} / \mathrm{ha}$ \\
\hline 1 & 102.2 & 89.6 & 12.6 & 85.1 & 74.6 & 10.5 \\
2 & 119.1 & 95.3 & 23.8 & 99.2 & 79.4 & 19.8 \\
3 & 113.7 & 100.4 & 13.3 & 94.7 & 83.6 & 11.1 \\
4 & 147.6 & 128.3 & 19.3 & 123.0 & 106.9 & 16.1 \\
5 & 111 & 83.3 & 27.7 & 92.5 & 69.4 & 23.1 \\
6 & 108.6 & 70.6 & 38 & 90.5 & 58.8 & 31.7 \\
\hline
\end{tabular}




\section{G. Fruit Quality and Characteristic}

It was observed from Table VIII, that treatments 1 and 2 had lowest rate of rotten yield compared to other treatments. Rotting of yield was highest in treatments 5 and 6 . The rotting was attributed to water logging, poor drainage that accelerated fungal infection in the tomatoes. Furrow treatments 3 and 4 had better drainage which enhanced low quantity of nonmarketable yield. There was no significant difference on the weight of tomatoes below $65 \mathrm{~g}$. This meant that fruit weight was independent of irrigation method. Treatments under hosepipe irrigation- overhead had highest rate of discolored fruits.

TABLE VIII: NON-MARKETABLE YIELD

\begin{tabular}{cccc}
\multicolumn{4}{c}{ TABLE VIII: NON-MARKETABLE YIELD } \\
\hline Treatment & $\begin{array}{c}\text { Wt }<65 \mathrm{~g} \\
(\mathrm{~kg})\end{array}$ & $\begin{array}{c}\text { Rotten } \\
(\mathrm{kg})\end{array}$ & $\begin{array}{c}\text { Discolored } \\
(\mathrm{kg})\end{array}$ \\
\hline 1 & 3.3 & 2 & 7.3 \\
2 & 2.3 & 7.5 & 14 \\
3 & 2.6 & 5.8 & 4.9 \\
& & & \\
4 & 3.8 & 10.2 & 5.3 \\
5 & 4.2 & 15.9 & 7.6 \\
6 & 3.5 & 30.5 & 4 \\
\hline
\end{tabular}

This was mainly due to sunshine and impact of water pressure during irrigation. This observation is in line with the recommendations by Department of agriculture, Forestry and Fisheries of the Republic of South Africa.

\section{H. Fruit Sizes}

Measurements conducted using venire caliper shown in Table VIII above revealed that most of the fruit sizes lie in the ranges between 10-25 $\mathrm{mm}$. However, the range between $15-20 \mathrm{~mm}$ in all treatments had the best fruit sizes which met the criteria for marketable yield. In respect to water management, treatment four had the most outstanding yield sizes attributed to proper drainage of excess water after rainfall event, this was followed closely by treatment 3 . Due to poor water management practices in treatment 5 and 6 , most of the yield sizes were in the range of 0-10 $\mathrm{mm}$.

\begin{tabular}{ccccccc}
\multicolumn{7}{c}{ TABLE IX: FRUIT SIZES } \\
\hline Treatment & $\begin{array}{c}0-5 \\
(\mathrm{~mm})\end{array}$ & $\begin{array}{c}5-10 \\
(\mathrm{~mm})\end{array}$ & $\begin{array}{c}10-15 \\
(\mathrm{~mm})\end{array}$ & $\begin{array}{c}15-20 \\
(\mathrm{~mm})\end{array}$ & $\begin{array}{c}20-25 \\
(\mathrm{~mm})\end{array}$ & $\begin{array}{c}>25 \\
(\mathrm{~mm})\end{array}$ \\
\hline 1 & 0 & 1 & 3 & 3 & 2 & 1 \\
2 & 0 & 2 & 1 & 5 & 2 & 1 \\
3 & 1 & 2 & 3 & 5 & 6 & 3 \\
4 & 0 & 3 & 6 & 9 & 8 & 4 \\
5 & 3 & 2 & 1 & 2 & 5 & 2 \\
6 & 5 & 2 & 2 & 3 & 1 & 0 \\
\hline
\end{tabular}

\section{Analysis of Variance on Average Weight}

The analysis of variance on the crop average weight was done as indicated as described by Tables X. It is observed that the Variance is 48.8205 with 15 degrees of freedom, Duncan's multiple range test. Experiment wise error rate is 0.0500 . It is indicated from this analysis that there are significant recommendations on which class we should expect a quality yield in terms of weight and general yield.
TABLE X(A): ANOVA ON AVERAGE WEIGHT Variate: Average Weight

\begin{tabular}{cccccc}
\hline \multicolumn{5}{c}{ Variate: Average Weight } \\
\hline $\begin{array}{c}\text { Source of } \\
\text { Variation }\end{array}$ & d.f & s.s & m.s & v.r & Fpr \\
\hline Block & 3 & 285.92 & 95.31 & 1.95 & \\
Stratum & 5 & 1583.49 & 316.7 & 6.49 & 0.002 \\
Treatment & 5 & 732.31 & 48.82 & & \\
Residual & 15 & 2601.72 & & & \\
Total & 23 & 26.9 & \\
\hline
\end{tabular}

TABLE X(B): ANOVA ON AVERAGE WEIGHT

\begin{tabular}{cccc}
\multicolumn{4}{c}{ TABLE X(B): ANOVA ON AVERAGE WEIGHT } \\
\hline Versus Mean & $\mathrm{t}$ & Significant \\
\hline Overhead Low & Overhead & -1.504 & No \\
Overhead Low & High & -2.089 & No \\
Overhead Low & Basin High & -2.291 & No \\
Overhead Low & Furrow Low & -4.590 & Yes \\
Overhead Low & Furrow High & -4.597 & Yes \\
Overhead Hig & Basin Low & -0.585 & No \\
Overhead High & Basin High & -0.787 & No \\
Overhead High & Furrow Low & -3.086 & Yes \\
Overhead High & Furrow High & -3.093 & Yes \\
Basin Low & Basin High & -0.201 & No \\
Basin Low & Furrow Low & -2.501 & Yes \\
Basin Low & Furrow High & -2.507 & Yes \\
Basin High & Furrow Low & -2.299 & Yes \\
Basin High & Furrow High & -2.306 & Yes \\
Furrow Low & Furrow High & -0.007 & No \\
\hline
\end{tabular}

\section{RECOMMENDATION AND CONCLUSION}

In view of the objectives of this research and results and discussions presented in earlier sections the following are deduced. Rotting of tomato fruits are as a result of water logging and poor root aeration causing deficiency in oxygen supply to the fruits. The study conducted on tomato revealed non-significant difference in the mean height at 70DAT. Canopy of the plants were more in treatment 4 than any other treatment. Water management practices have a big implication on the crop yield, it has a bearing that yield is directly proportional to water management practices, this should be followed by detailed soil and water analysis. The findings help fight poverty and avail the much-needed income as well as providing household food security.

Most of agronomic experiments require repeating the experiment in time and space for three growing seasons, to further bolster the validity of this finding, it recommended that the experiment be repeated in other agronomic seasons, this is because experiments of this nature have ability to resolve the problem of water scarcity and avail the muchneeded household nutritional need. This experimental study was carried out in an open field making it susceptible rain even if the intention is to supply $50 \%$ of irrigation water, a amore controlled environment like the study in a greenhouse is recommended because it provide a better controlled environment yielding a more accurate result.

\section{CONFLICT OF INTEREST}

The authors of this manuscript declare that no conflict of interest was involved as it was generated from live experiments and developed as a team. 


\section{REFERENCES}

[1] Jensen C.R.; Battilani A.; Plauborg F.; Psarras G.; Chartzoulakis K. Janowiak F.; Stikic R.; Jovanovic Z.; Li G.; Qi X.; Liu F.; Jacobsen S.; Andersen M. N. Deficit irrigation based on drought tolerance and root signalling in potatoes and tomatoes. Agricultural Water Management, 2010;98:403-413.

[2] Matos E. S., Shirahige F. H., Melo P. C. T. Desempenho de híbridos de tomate de crescimento indeterminado em função de sistemas de condução de plantas. Horticultura Brasileira, 2012;30:240-245.

[3] Robinah Sonko, Makerere University, Evelyn Njue, ETC - East Africa James M. Ssebuliba, Makerere University, Andre de Jager, Wageningen University and Research Center, The horticultural sector in Uganda, January, 2015.

[4] Lopes FB, Souza F, Andrade EM, Meireles ACM, Caitano RF Determinação do padrão do manejo da irrigação praticada no Perímetro Irrigado Baixo a Acaraú, Ceará, via análise multivariada. Irrig. Botucatu. 16(3):301-316. Lycopersicon esculentum Mill.) For fresh consumption. Ciência Rural, 2004;34:329-335.

[5] Siebert, S., Burke, J. , Faures, J. M.,; Frenken, K., Hoogeveen, J. , Döll, P., Portmann, F. T. Groundwater use for Irrigation, a Global Inventory, Hydrol. Earth Syst. Sci., 14(10):1863-1880, 2010.

[6] Ferreira S. M. R., Freitas R. J. S., Lazzari E. N. Identity and quality standards of tomatoes. Visão Acadêmica, Curitiba, v. 5, n. 1, p. 19-26, Jan.- Jun./2004.

[7] Hamlyn, G.Jones, (2004)Irrigation scheduling: advantages and pitfalls of plant-based methods Journal of Experimental Botany, 2004;55(407):2427-2436. https//doi.org/10.1093/jxb/erb213.

[8] José A. Monte; Daniel F. de Carvalho; Leonardo O. Medici; Leonardo D. B. da SilvaII; Carlos Pimentel. Growth analysis and yield of tomato crop under different irrigation depths, 2013.

[9] Pereira, A. R.; Machado, E. C. Análysis of quantitative do crescimento vegetal. Campinas: Instituto Agronômico de Campinas. 1987. 33p. Boletim Técnico, n.114.

[10] Favati, F.; Lovelli, S.; Galgano, F.; Miccolis, V.; Di Tommaso, T.; Candido, V. Processing tomato quality as affected by irrigation scheduling. Scientia Horticulturae, p122, 2009.

[11] FAO. Irrigation and Drainage Paper 56. FAO, for wheat crop using field experiment and simulation modeling: Agri. water Manage. 96.

[12] Prakash, B. A. Yield and Fruit Quality of Tomatoes (Lycopersicon Esculentum Mill)., 53(2):102-107. 2012.

[13] Allen R.G., L.S. Pereira D. Raes and M. Smith, 1998. Crop Evapotranspiration Guidelines.

[14] Al-Kaisi, M. M and I. Broner (3/13). Quick Facts... Water stress during critical growth periods reduces yield and quality of crops.extension.colostate.edu/topic-areas/.../crop-water-use-andgrowth-stages-4-715.

[15] Douglas C. Montgomery. Applied statistics and probability for engineers. - 3rd ed. p. cm. ISBN 0-471-20454-4 (acid-free paper) Runger, George C. II. Title. QA276.12.M645 2002 519.5-dc21 2002016765 